\title{
An Unusual Cause of Bleeding on the Floor of Mouth: Leech Infestation
}

\section{Ağız Tabanı Üzerinde Nadir Bir Kanama Nedeni: Sülük İnfestasyonu}

\author{
Yunus Kantekin ${ }^{1}$, Kamran Sarı ${ }^{1}$, Mahmut Özkırış ${ }^{2}$, Zeliha Kapusuz Gencer ${ }^{1}$ \\ 'Bozok Üniversitesi Tıp Fakültesi, Kulak Burun Boğaz Anabilim Dalı, Yozgat, Türkiye \\ ${ }^{2}$ Acıbadem Hastanesi, Kulak Burun Boğaz Anabilim Dalı, Kayseri, Türkiye
}

\section{ABSTRACT}

Leech infestation is a very rare phenomenon in humans. It mostly occurs in humans when rural untreated water is drunk or while swimming in streams or lakes. When leeches adhere to the mucous membrane, they ingest blood. Thus, they can sometimes cause severe anemia that may require blood transfusion. We report a case that was referred to emergency service with bleeding in the floor of the mouth. A 10-year-old child was referred to the emergency service of a city hospital with a complaint of swelling in the floor of the mouth and spitting of blood. The patient was promptly taken to the operating room. Using local anesthesia, a surgical incision was made, and a moving, dark brown foreign body was removed from the floor of the mouth and identified as a leech. Leech endoparasitism should be considered as a cause of unexplained anemia due to bleeding from the throat. Accordingly, leech infestation must be considered in differential diagnosis when a patient complains of spitting of blood, hoarseness, or dysphagia. (Turkiye Parazitol Derg 2015; 39: 323-5)

Keywords: Leech infestation, Anemia, Oral cavity

Received: 16.04 .2015

Accepted: 07.10 .2015

\section{Öz}

Sülük infestasyonu insanlarda çok nadir görülen bir olgudur. Sıklıkla kırsal bölgede yaşayan işlenmemiş su içen veya dere ve akarsularda yüzen insanlarda görülür. Sülükler mukozal membranlara bağlanarak kan yutarlar. Bu nedenle bazen kan transfüzyonu gerektirebilen ciddi anemiye neden olabilirler. Bu olgu sunumunda ağız tabanında kanama ile acil servise başvuran bir hasta sunulmuştur. 10 yaşında bir çocuk ağız tabanında şişlik ve kan tükürme şikayeti ile devlet hastanesi acil servisine başvurdu. Hasta hemen ameliyathaneye alındı. Lokal anestezi ile cerrahi insizyon yapılarak koyu kahverengi yabancı cisim dikkatli bir şekilde çıkarıldı ve çıkarılan bu yabancı cismin sülük olduğu görüldü. Sülük endoparazitizm boğazda kanama yaparak açıklanamayan anemiye neden olabilir. Bu nedenle kan tükürme, ses kısıklığı ve yutma güçlüğü şikayeti ile başvuran bir hastada sülük infestasyonu ayırıcı tanıda düşünülmelidir. (Turkiye Parazitol Derg 2015; 39: 323-5)

Anahtar Kelimeler: Sülük infestasyonu, Anemi, Oral kavite

Geliş Tarihi: 16.04.2015

Kabul Tarihi: 07.10.2015

\section{INTRODUCTION}

Leech infestation is a very rare phenomenon in humans, mostly occurring in humans when rural untreated water is drunk or while swimming in streams or lakes (1). They may localize in the upper respiratory or upper digestive tract, such as the nose, pharynx, and esophagus, or rarely in the larynx (2). Leeches are blood sucking worms and may be of different color or shape. When leeches adhere to the skin or mucous membrane, they ingest blood. Thus, they sometimes can cause severe anemia that may require blood transfusion (3). Leech saliva contains molecules, such as hirudin, which is a highly effective anticoagulant (4). This may cause bleeding and anemia in serious infestations. To the best of

Address for Correspondence / Yazışma Adresi: Dr. Yunus Kantekin. E.mail: ykantekin@yahoo.com DOI: 10.5152/tpd.2015.4254

CCopyright 2015 Turkish Society for Parasitology - Available online at www.tparazitolderg.org

CTelif hakkı 2015 Türkiye Parazitoloji Derneği - Makale metnine www.tparazitolderg.org web sayfasından ulaşılabilir. 




Figure 1. Removed leech that was dark brown in color

our knowledge, this is the first case wherein a leech was found in the floor of the mouth, i.e., the oral cavity that is located under the tongue. We report a case that was referred to the emergency service with bleeding in the floor of the mouth.

\section{CASE REPORT}

A 10-year-old child was referred to the emergency service of the city hospital with a complaint of swelling in the floor of the mouth and spitting of blood. The examination of the oral cavity revealed a foreign body $2 \times 3 \mathrm{~cm}$ in size. The blood count and clotting test were normal, and the patient was promptly taken to the operating room. Using local anesthesia, a surgical incision was made, and a moving, dark brown foreign body was removed from the floor of the mouth and identified as a leech (Figure-1). The bleeding stopped soon after the removal of the leech, and the patient was discharged the following day. The patient lived in a rural area and used to swim in a nearby river, which is probably where he was infested with the leech.

\section{DISCUSSION}

Leeches are blood-sucking annelid worms belonging to the subclass Hirudinea from the Phylum Annelida. They are equipped with a large and small sucker. The mouth is located on the small sucker and has three jaws with sharp teeth that make a Y-shaped incision in the skin. Leeches can ingest 10 times their own weight in blood. The infestation is painless because the leech has a local anesthetic in its saliva (5).

Leech infestation in the upper aero-digestive tract is rarely observed. Leeches usually infest animals and humans when water from natural sources is drunk or while swimming in rivers and lakes. When leeches enter the body, they may attach to the mucosa of the entire upper aero-digestive tract. They do not carry diseases; however, because they are infected with symbiotic Aeromonas hydrophila and Aeromonas veronii, which live in the intestinal tract of the leech, they may lead to infections in 4\%$20 \%$ of patients. They may rarely cause death in extreme cases. If leeches are attached to the upper aero-digestive tract, they can cause dyspnea, hemoptysis or hematemesis, bleeding, or, and in rare cases globus sensation (4).
Leech infestation is observed more in the upper respiratory tract than in the upper digestive tract. Kaygusuz et al. presented the case of four patients who had leech infestation in the larynx (6). Another case by Solomon reported a case of acute laryngotracheal obstruction in a 12-year-old boy (7). All cases were diagnosed by indirect laryngoscopic examination. The leeches were removed with forceps in direct laryngoscopy under general anesthesia. Oghan et al. reported a case of a patient who had a leech infestation in the palate (8). They removed the leech via electrocauterization. To the best of our knowledge, our report is the first case in which a leech was observed in the floor of the mouth. The leech was carefully removed because it can easily rupture. Rupturing of the leech could result in continued bleeding because the apical part of the leech body contains hirudin, a strong anticoagulant. Some authors advise the use of lidocaine before removing the leech because this medication causes relaxation of the head suckers (1). After removal of the leech, the blood count and clotting test were normal, and no anemia could be diagnosed. Moreover, leech infestation may be observed in the nose, nasopharynx, and eye. Ghimire et al. (9) reported a unilateral nostril epistaxis caused by leech infestation. Bilgen reported leech-caused recurrent epistaxis during 4 months (10). Alcelik et al. (11) diagnosed a leech as a foreign body in the eye of a Turkish child. In patients with leech infestation, bleeding is the most frequently observed symptoms, whereas in rare cases, anemia can be diagnosed (12).

Hirudotherapy is an ancient therapy modality. For many years, leeches have been used in medicine to enhance the blood flow to the skin and muscle flaps, thereby improving blood circulation and helping quicker healing (13). The saliva of leeches contain several anticoagulants and a histamine, such as a vasodilator, which are useful for providing critical venous outflow for compromised tissue replants (14). Biologically active substances improve blood circulation in the organs; serve as a thrombolytic, anti-inflammatory substance; stimulate immunity promote tissue nutrition; and strengthen the immune systems (9).

\section{CONCLUSION}

Leech infestation is usually observed in individuals who drink contaminated spring water or swim in streams. Leech endoparasitism should be considered as a cause of unexplained anemia due to bleeding in the throat. Accordingly, leech infestation must be considered in differential diagnosis when a patient complains of spitting of blood, hoarseness, or dysphagia.

Informed Consent: Written informed consent was obtained from the patient.

Peer-review: Externally peer-reviewed.

Author contributions: Consept - Y.K., K.S., M.Ö., Z.K.G.; Design - Y.K., K.S., M.Ö., Z.K.G.; Supervision Y.K., K.S., M.Ö., Z.K.G.; Funding - Y.K., K.S., M.Ö., Z.K.G.; Materials - Y.K., K.S., M.Ö., Z.K.G.; Data Collection and/or Processing - Y.K., K.S., M.Ö., Z.K.G.; Analysis and/or Interpretation - Y.K., K.S., M.Ö., Z.K.G.; Literature Review - Y.K., K.S., M.Ö., Z.K.G.; Writer - Y.K., K.S., M.Ö., Z.K.G.; Critical Review - Y.K., K.S., M.Ö., Z.K.G.

Conflict of Interest: No conflict of interest was declared by the authors.

Financial Disclosure: The authors declared that this study has received no financial support. 
Hasta Onamı: Yazılı hasta onamı hastadan alınmışıิır.

Hakem Değerlendirmesi: Dış Bağımsız.

Yazar Katkıları: Fikir - Y.K., K.S., M.Ö., Z.K.G.; Tasarım - Y.K., K.S., M.Ö., Z.K.G.; Denetleme - Y.K., K.S., M.Ö., Z.K.G.; Kaynaklar - Y.K., K.S., M.Ö., Z.K.G.; Malzemeler - Y.K., K.S., M. Ö., Z.K.G.; Veri Toplanması ve/veya işlemesi - Y.K., K.S., M.Ö., Z.K.G.; Analiz ve/veya Yorum - Y.K., K.S., M.Ö., Z.K.G.; Literatür taraması - Y.K., K.S., M.Ö., Z.K.G.; Yazıyı Yazan - Y.K., K.S., M.Ö., Z.K.G.; Eleştirel İnceleme - Y.K., K.S., M.Ö., Z.K.G.

Çıkar Çatışması: Yazarlar çıkar çatışması bildirmemişlerdir.

Finansal Destek: Yazarlar bu çalışma için finansal destek almadıklarını beyan etmişlerdir.

\section{REFERENCES}

1. Rajati M, Irani S, Khadivi E, Bakhshaee M. An unusual cause of dysphonia with hemoptysis: a laryngeal live leech. Iran J Otorhinolaryngol 2014; 26: 181-3.

2. García AC, Martín AM, De Luna Gijón CA, Martín Anaya AS, Mondéjar $A R$. Leech in the epiglottis: an unusual discovery in our times. Am J Otolaryngol 2002; 23: 91-2. [CrossRef]

3. al-Hadrani A, Debry C, Faucon F, Fingerhut A. Hoarseness due to leech ingestion. J Laryngol Otol 2000; 114:145-6. [CrossRef]
4. Mekonnen D. Leech Infestation. the unusual cause of upper airway obstruction. Ethiop J Health Sci 2013; 23: 65-8.

5. Adam R, Zakrzewski P. Therapeutic use of leeches. University of Toronto Medical Journal 2001; 79: 65-7.

6. Kaygusuz I, Yalcin S, Keleş E. Leeches in the larynx. Eur Arch Otorhinolaryngol 2001; 258: 455-7. [CrossRef]

7. Solomon E. Leech-an unusual cause of (laryngo-tracheal) obstruction. Ethiop Med J 1991; 29: 141-2.

8. Oğhan F, Güvey A, Özkırış M, Gülcan E . Oropharyngeal leech infestation and therapeutic options. Turkiye Parazitol Derg 2010; 34: 200-2. [CrossRef]

9. Ghimire A, Acharya A. Unusual cause of unilateral epi-staxis: nasal leech infestation. JNMA J Nepal Med Assoc 2008; 47: 38-40.

10. Bilgen $C$, Karci B, Uluöz U. A nasopharyngeal mass: leech in the nasopharynx. Int J Pediatr Otorhinolaryngol 2002; 64: 73-6. [CrossRef]

11. Alcelik T, Cekic O, Totan Y. Ocular leech infestation in a child. Am J Ophthalmol 1997; 124: 110-2. [CrossRef]

12. Vegari S, Ghaffarlou M, Davarimajd L, Golzari SE . Globus Sensation Due to a Mobile Foreign Body in a 41-year-old Female. J Cardiovasc Thorac Res 2012; 4: 29-30.

13. Pilcher H. Medicinal leeches: stuck on you. Nature 2004; 432: 10-1. [CrossRef]

14. Kraemer BA, Korber KE, Aquino TI, Engleman A. Use of leeches in plastic and reconstructive surgery: a review. J Reconstr Microsurg 2001; 40: 381-6. 